\title{
Molluscan and sedimentological sequences of the late Quaternary deposits of Morsott region (NE Algeria) and their paleoenvironmental implication
}

\author{
Smaine Chellat ${ }^{1,2^{*}}$, Lotfi Toubal ${ }^{3}$, Abderrezak Djerrab ${ }^{4}$, Ahcene Bourefis ${ }^{1}$, Belhadj Hamdi-Aissa ${ }^{5}$ \\ and Sihem Salmi-laouar ${ }^{6}$ \\ ${ }^{1}$ Laboratoire de géologie de l'environnement, Université Constantine 1, route Ain El Bey Zouaghi slimane Constantine 25000, Algeria \\ ${ }^{2}$ Laboratoire de géologie du Sahara, Département de géologie, Université Kasdi Merbah, Ouargla 30000, Algeria \\ ${ }^{3}$ Département génie mécanique, Université du Québec à Trois-Rivières 3351, boul. des Forges, C.P. 500, Trois-Rivières, G9A 5H7, \\ Québec, Canada \\ ${ }^{4}$ Département de l'histoire et d'archéologie, Université 8 mai 1945, Guelma, Algeria \\ 5 Département d'agronomie, Université Kasdi Merbah, Ouargla 30000, Algeria \\ ${ }^{6}$ Département de géologie, Université Badji Mokhtar, Annaba 23000, Algeria
}

Received: 20 December 2017 / Accepted: 6 October 2018

\begin{abstract}
The late Quaternary sequences of north-eastern Algeria composed of alternating dark and light layers, which are rich in molluscan fauna, could correspond to synchronous environmental phases. The facies variations of the Morsott Region deposits were systematically sampled as part of a sedimentological and malacological study in order to establish a palaeoenvironmental and climatic reconstruction of the late Quaternary. The alternation of sandy clayey silts levels, which contain abundant molluscan hygrophilous organisms, indicates an isostasis cycle followed, at the top, by a succession of rhexistasis and biostasis cycles. The molluscan record shows a dominant succession of xerophilous organisms in relation to the hygrophilous organisms. The faunistic richness in the fine levels is linked to sub-humid periods where the region has suffered numerous floods. The reduction in the number of species in the coarse levels comes is likely due to desiccation when the climate was semi-arid. This study is new in Algeria and will provide an insight into climatic changes. Further research will be required in order to understand the fluvial dynamics during the Quaternary.
\end{abstract}

Keywords: fluvio-lacustrine / morsott / malacology / isostasis / hygrophilous organisms

Résumé - Malacologique et sédimentologique séquences des dépôts Quaternaire tardif de la région de Morsott (Nord-Est algérien) et ces conséquences paléoenvironnementales. Les séquences quaternaires tardives du nord-est algérien, composées par des alternances de niveaux sombres et clairs et contenant un riche faune malacologique, pourraient correspondre à des phases environnementales synchrones. Les variations du faciès et l'échantillonnage systématique des dépôts de la région de Morsott ont fait l'objet d'une étude sédimentologique et malacologique afin d'établir une reconstitution paléoenvironnementale et climatique à la fin du Quaternaire. L'alternance des niveaux de silts argileux sableux, riches en faune malacologique (hygrophiles), indique un cycle d'isostasie suivi au sommet par une succession de cycles de rhéxistasie et de biostasie. Le registre malacologique montre une succession dominante d'organismes xérophiles par rapport aux organismes hygrophiles. La richesse faunistique dans les niveaux fins est liée à des périodes subhumides où la région a souffert de nombreuses inondations. La réduction du nombre d'espèces dans les niveaux grossiers provient d'une phase de dessiccation lors d'un climat semi-aride. Cette étude est nouvelle en Algérie et fournira un aperçu des changements climatiques. D’autres recherches seront nécessaires pour comprendre la dynamique fluviale au cours du quaternaire.

Mots clés : fluvio-lacustre / morsott / malacologie / isostasie / organismes hygrophiles

*Corresponding author: smaine.chellat@gmail.com 


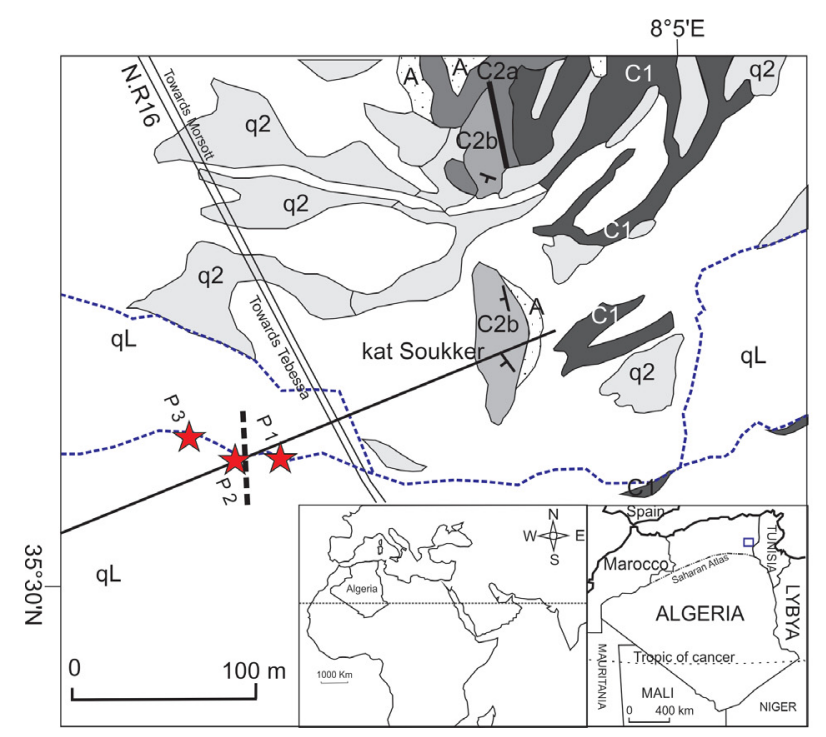

\section{Legende}
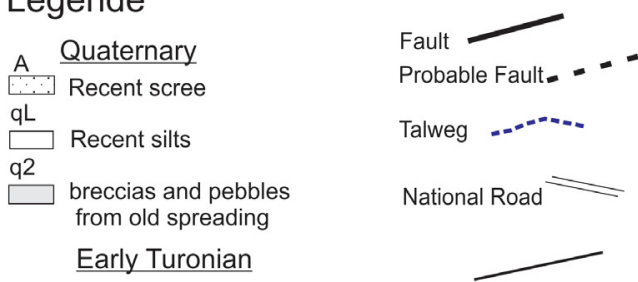

$\mathrm{C} 2 \mathrm{~b}$ Late Legerian

Massive limestones alternating with levels more argillaceous into small benches

C2a Early Legerian

Platy marls and limestones

C1 Cenomanian

passed coquinoide limestones

National Road

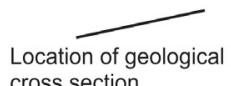

cross section

Profiles P1, P2, P3 and Sampling area

Area of study $\square$

Fig. 1. Geographical and geological map of the studied region (Dubourdieu, 1956). The morsott profiles studied are located in a sedimentary basin, consisting mainly of the Cretaceous formations covered by fluvio-lacustrine deposits of quaternary age. These quaternary deposits come from several phases of alterations and erosions, these different phases produced a coarse and fine material, and which was deposited on the slopes and plains forming a cover for the old lands.

\section{Introduction}

The molluscan and paleoenvironmental analyses of the Quaternary continental deposits from Morsott, NE Algeria, Africa (Fig. 1), have been limited compared to others areas, in North Africa, such as, the work carried out on recent Quaternary deposits in El Akarit wadi (Rognon et al., 1983), wadi Sbeitla in Tunisia (Zerai, 2006), and the Ksabi Basin (Middle Moulouya Basin) in Morocco (LimondinLozouet et al., 2012). These deposits are of interest in stratigraphic, palaeoenvironment and Quaternary climate reconstitutions. In Tunisia, (Zerai, 2006) described the muddy continental deposits of the Pleistocene to Holocene, including a variety of snails, the majority of which thrive, in moderately xerophilous conditions, which were covered with thin soil and sometimes limestones. These molluscs appeared in variable quantities in the various Holocene levels. A malacological assemblage collected at Morsott, in the municipality of Tebessa in northeastern Algeria, has a similar molluscan content to those found in Morocco. These Holocene molluscs record the changes between sub-arid and sub-humid climates (Lefèvre, 1985, 1989; Lefèvre and Ballouche, 1991; Limondin-Lozouet 2002a, b). Therefore, molluscs appear to be suitable proxies for reconstructing paleoenvironments in these morphostratigraphic contexts (Haddoumi et al., 2008), despite the lake of information regarding Quaternary fossils and nonmarine molluscs of North Africa (Sparks and Grove, 1961). This paper presents a sedimentological and systematic study of the molluscan species encountered, with the purpose of suggesting a paleoenvironmental approach to study of the Quaternary formations of the Morsott region. Fluvio lacustrine deposits dated in Tunisia (Zerai, 2006), and in the south of Tebessa (Defaflia, 2013), gave an upper Pleistocene to Holocene age.

This study will show an approach about the contribution of the molluscs, characterizing the area. The identification of the molluscan species is based initially on correlations made by recent works associated with archaeological studies of the Neolithic (Roubet and Hachi 2008; Djerrab et al., 2013), and older research, such as Terver (1839), Bourguignat (1864), Pallary (1901).

\subsection{Regional setting}

The Morsott Region (35 $35^{\prime} 20.95^{\prime} \mathrm{N} ; 8^{\circ} 3$ '38.83 "E; $789 \mathrm{~m}$ ) is located towards the eastern end of the Saharan Atlas (Algerian-Tunisian border). The region is characterized by a semi-arid climate (cold winters and hot summers). Inter-annual precipitation is irregular and averages $379.00 \mathrm{~mm}$. The average humidity is $41.41 \%$, with a maximum of $69.63 \%$ in April. The average annual temperature is $15.20^{\circ} \mathrm{C}$. The Morsott area is influenced by northern rains in the winter and warm sirocco winds in the summer. The study area is limited to the north by a sub-humid bioclimatic stage and to the south by the sub-arid domain (Cote, 1998; Gouaidia, 2008; Mebarki, 2005). Rainy periods allowed the development of fine soils (palaeosols) during the Quaternary, these periods were interspersed with stages of low rainfall marked by coarse soils (Zeuner, 1970). The observed formations date from the Triassic, Cretaceous and Tertiary periods (Dubourdieu, 1956). These deposits have undergone alteration, transport and resedimentation and take many forms, slope breaks, Glacis or (alluvial cones), or alluvial terraces (Fig. 1).

\subsection{Stratigraphy}

2.2.1 the Quaternary series can be divided into two parts: the Pleistocene and Holocene

The Pleistocene represents the base level of the studied profiles and is mainly composed of mixed deposits, oftenangular (frost-riven). These deposits are homometric and of calcareous origin due to freeze-thaw processes, and the grains 
SW

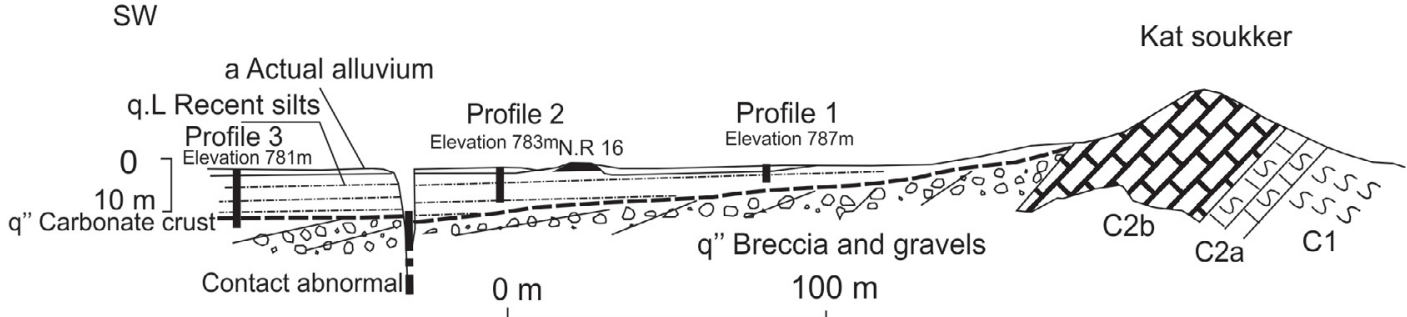

$\mathrm{NE}$

Profile 3

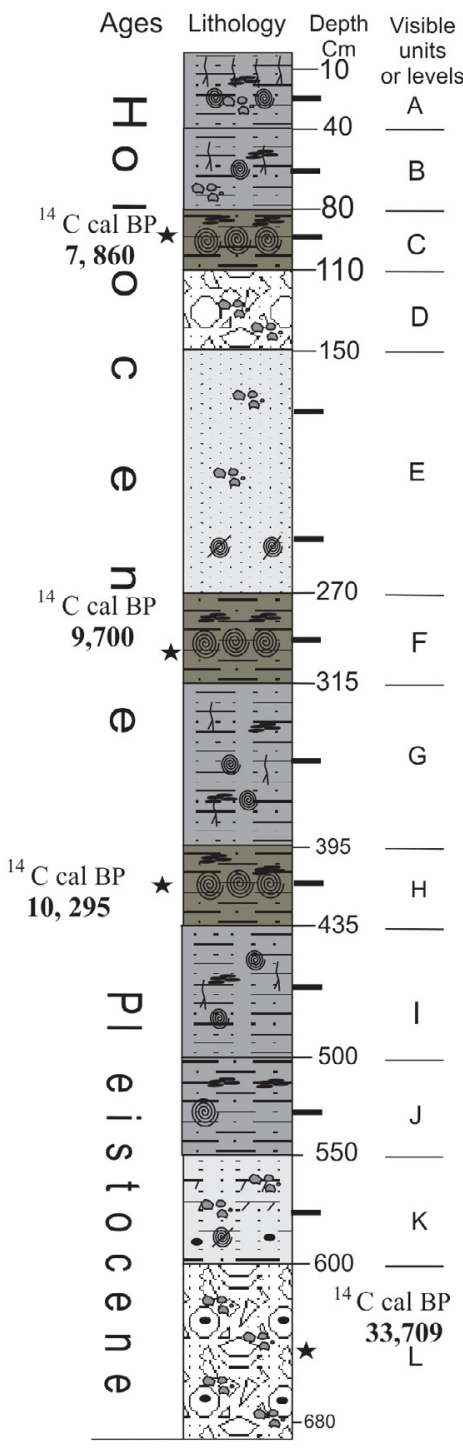

Profile 1

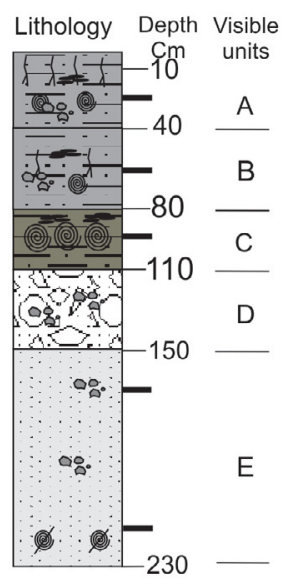

Profile 2

Lithology Depth Visible

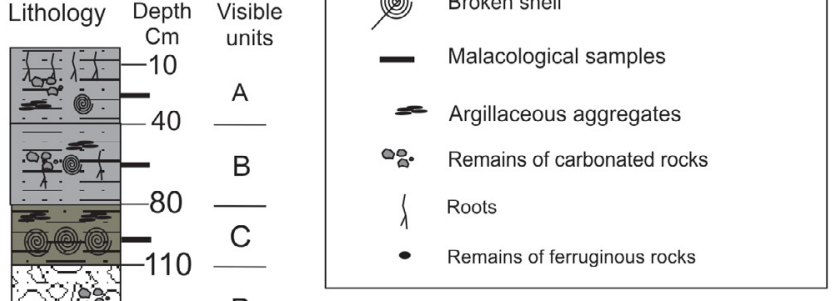

C2a Lower Turonian Marly limestone

C1 Cenomanian Marl

N.R National Road

Lithological set 1

Sandy clayey silts

Lithological set 2

Sandy silts

Lithological set 3

Silty sands

Lithological set 4

Breccias and gravels with

matrix supported

$T \rightarrow$ Carbonate crust

(2) Complet shell

(2)) Broken shel

Malacological samples

$=$ Argillaceous aggregates

Remains of carbonated rocks

- Remains of ferruginous rocks

Fig. 2. Stratigraphic profiles of the Morsott Holocene deposits, showing the sampling locations and extent of the malacological zones. Systematic sampling is shown in Figure 2 by black dashes. Coarse and fine deposits represent the alteration products in the Morsott region, an indication of a change in climatic conditions and sedimentation, the passage between coarse basal deposits rich in calcareous encrustations of Pleistocene age. at the base, with alternating sandy and silty loamy levels rich in snails at the summit, indicating the passage to a Holocene period more favorable to life. 
Table 1. Sedimentological parameters of the Holocene deposits in the Morsott area. The sedimentological parameters determined to the fine fraction, less than $2 \mathrm{~mm}$, show variable mode, average, index asymmetry, and flattening values indicating a medium to high energy carrier current regime at the base of the series (unit $\mathrm{K}$ and $\mathrm{L}$ ) and from medium to low during the Holocene.

\begin{tabular}{|c|c|c|c|c|c|}
\hline $\begin{array}{l}\text { Designations } \\
\text { Units }\end{array}$ & $\begin{array}{l}\text { Breccias and pebbles set } \\
\text { D, L }\end{array}$ & $\begin{array}{l}\text { Silty sands set } \\
\mathrm{K}, \mathrm{E}\end{array}$ & $\begin{array}{l}\text { Sandy clayey silts set } \\
\text { C, F, H, J }\end{array}$ & $\begin{array}{l}\text { Sandy silts set } \\
\text { A, B, G, I }\end{array}$ & \\
\hline Mode in $\mu \mathrm{m}$ & 500 & 350 & 380 & 400 & Characteristics \\
\hline Sorting So & -0.1 & -0.9 & -0.5 & -0.35 & Grains very well classified \\
\hline Kurtosis $\mathrm{Ku}$ & 0.3 & 0.1 & 0.1 & 0.2 & $\begin{array}{l}\text { The curves are very platykurtic } \\
\text { with heterogeneous composition }\end{array}$ \\
\hline $\begin{array}{l}\text { Classification } \\
\text { according to Folk (1954) }\end{array}$ & Silty facies & Silty facies & Silty facies & Silty facies & \\
\hline
\end{tabular}

in the deposits have a very weak blunted index due to a short river transportation phase and short distances that separate them from the calcareous source, and the larger sections are covered by roughly $1 \mathrm{~cm}$ calcareous crust (Hentati, 1977, 1978). The calcareous crust is superficial, ranges between 200 and $250 \mathrm{~km}^{2}$ and is whitish to pinkish in color. The crust lacks homogeneity and hardens gradually towards its upper part. Its thickness can oscillate between a few $\mathrm{dm}$ to approximately $2 \mathrm{~m}$, but, in most cases, it is $1 \mathrm{~m}$ to $1.50 \mathrm{~m}$ thick. In particular, it covers the gypsiferous layers of the Trias, Cenomanian and Senonian marls, Turonian limestones and Miocene sandstones. It has a high iron oxide content, with a frequent presence of dietritic quartz, and shell-fragments.

The Holocene sequence is an alternation of sandy silts and sandy clayey silts and has an average thickness of 6 meters. These levels are recognized by the species of snail contained within.

\section{Methodology}

The three profiles studied from Morsott (Figs. 1 and 2) have a maximum thickness of $7 \mathrm{~m}$. Samples were taken systematically with an interval of $10-15 \mathrm{~cm}$ in the fine units and of $20 \mathrm{~cm}$ in the thick units. The dates used in this study are based on a radiocarbon analysis (absolute dating using 14C), conducted in A.E. Lalonde AMS Laboratory using an accelerator mass spectrometer. The absolute dating was undertaken on broken shells (diameter less than $2 \mathrm{~mm}$ ) from the shell-rich levels along the profile the most representative of the levels encountered. The sedimentological analysis was performed using a laser-particle-measurement instrument (Coulter LS1330 at the University of Perpignan); the mineralogical identification was firstly made with a binocular magnifying glass, then by a diffractometer with the X-ray Bruker D8 Advance at the University of Biskra; the spectra was treated by the Much 2.0 software. Molluscan identification was undertaken following standard protocols (Evans, 1972; Limondin-Lozouet, 2002b; Lozek, 1964; Puisségur, 1976; Rousseau, 1986, 1987). The same volume of samples was taken from all profiles and levels. The large shells were harvested manually, and all species of the adult size class, ranging from 0.5 to $25 \mathrm{~mm}$, were extracted or sieved from the fine fraction with a $2 \mathrm{~mm}$ sieve. Smaller species and broken shells, invisible to the naked eye or existing as debris, which could not be identified, were excluded from the study. However, these more representative of environmental conditions, and so were used in the palaeoenvironmental reconstruction.

\section{Results}

Three detailed profiles of the Holocene deposits at Morsott revealed 11 sedimentary formations which were defined and classified from $\mathrm{A}$ at the top to $\mathrm{L}$ in the bottom, according to the sedimentological analysis by Chellat (2009). The units (levels) which presented similar sedimentological characters were grouped into four lithological sets. Set 1 was composed of sandy clayey silts, units $\mathrm{C}, \mathrm{F}, \mathrm{H}, \mathrm{J}$; the second lithological set grouped together the sandy silts, (units A, B, $\mathrm{G}, \mathrm{I}$ ); levels $\mathrm{E}$ and $\mathrm{K}$, the silty sands were grouped into set 3; while litological set 4 , contained units $\mathrm{D}$ and $\mathrm{L}$ the breccias and pebbles (Tab. 1).

Lithological set 1: light brown sandy clayey silts, according Munsell chart color system (2.5 YR 4/10), poor in gravel, sometimes rich in broken shells, with a slight dip towards the centre of the valley and a diffuse transition to the other adjacent levels. The argillaceous, acicular aggregates are polyhedral, of indurated consistency, with millimetric porosity and acicular. Bioturbation occurs as millimetric roots and burrows.

Lithological set 2: dark brown to blackish (5 YR 3/6) sandy silts, poor in gravels, with a slight dip towards the centre of the valley and a sharp boundary with the adjacent sets. The argillaceous aggregates are polyhedral in consistency, indurated in the dry state and become plastic in the presence of water, with abundant cracks. Bioturbation is manifested as millimetric roots and this level is rich in malacological species (snails).

Lithological set 3: light brown (5 YR 4/8) silty sands, weakly dipping towards the centre of the valley, with a distinct transition between the adjacent levels. The argillaceous aggregates are polyhedral, of loose consistency and have millimetric porosity. Bioturbation manifests as millimetric roots. Some coal debris is present. 
Table 2. Radiocarbon dating results. Calibration was performed using OxCal v4.2.4 (Bronk Ramsey, 2009) and the IntCal13 calibration curve (Reimer et al., 2013). Material codes are described in Crann et al. (2017). Absolute dating established on the three fine levels, TM1 to TM3 considered Holocene and on the basic level, Pleistocene age TM4, the ages of the samples are given in thousands of years before the present (B. P).

\begin{tabular}{|c|c|c|c|c|c|c|c|c|}
\hline Lab ID & $\begin{array}{l}\text { Submitter } \\
\text { ID }\end{array}$ & Material & $\begin{array}{l}\text { Mat. } \\
\text { Code }^{a}\end{array}$ & ${ }^{14} \mathrm{C}$ yr BP & & $\pm \mathrm{F}^{14} \mathrm{C}$ & \pm & cal BP \\
\hline UOC-4852 & TM2 & shells & $\mathrm{S}$ & 8687 & 45 & 0.3391 & 0.0019 & $9780-9540(95.1 \%)$ \\
\hline UOC-4854 & TM4 & carbonate & $\mathrm{SN}$ & 29919 & 160 & 0.0241 & 0.0005 & 34346-33709 (95.4\%) \\
\hline
\end{tabular}

Lithological set 4: the set consists of matrix-supported breccias and gravels (2.5 YR 3/8). There is a sharp transition to the adjacent levels. The argillaceous aggregates have diameters between 0 and $10 \mathrm{~cm}$, are sub-rounded in shape and are worn, with breaks and sharp edges. The bioturbation seen in the other lithological sets is absent.

The majority of the sediments experienced low to medium transportational energy, as indicated by the very good sorting of fine grains. The sorting (So), had negative values in the majority of units, and their heterogeneous compositions, the kurtosis $(\mathrm{Ku})$, had several populations, and low values, the dissymmetry coefficient of skewness (SK), had low, negative values. The classification of the fine fraction, according to the ternary triangle of Folk (1954) shows that these units are silty sands, sandy silts and sandy clayey silts (Tab. 1).

Levels D, K and L, which belong to lithological sets 3 and 4 , contain very low levels of organic matter, while levels $\mathrm{D}, \mathrm{K}$, L. Levels A, C, F, H, and J contain a significant amount of organic matter $\sim 2.8-3.5 \%$. The other units were comprised of less than $2 \%$ organic matter (Fig. 2). The estimated carbonate ratios are between 42 and $55 \%$ for all the units, and the average values, which increase with depth except for levels $\mathrm{K}$ and $\mathrm{L}$, exceed $74 \%$.

Microscopic examination shows angular to sub-rounded grains composed mainly of carbonate rocks debris $(5 \%$ on average), fossil fragments ( $75 \%$ on average), clay aggregates ( $20 \%$ on average), snail debris $(2 \%)$ and small quantities $(<3 \%)$ of blunted quartz grains, ferruginous rock debris and coal debris.

\subsection{Absolute dating}

Radiocarbon analysis of four Morsott samples was performed in the AE. Lalonde AMS Laboratory (Ottawa), (Tab. 2). The ages range from $33709 \mathrm{cal}$. BP (Late Pleistocene) to $7860 \mathrm{Cal} \mathrm{BP}$ (mid-Holocene).

\subsection{Features of the deposit medium}

The energies of the transport currents were variable; they were medium to low in most of the described units of the three profiles and alternated between short phases of high energy that enabled the transport of large boulders and sands. The semi-quantitative analysis established by the XRD diffraction spectra of clays shows a dominance of illite and smectite, followed by chlorite and kaolinite. Illite is the principal mineral and is ubiquitous; illite is approximately $16.45 \%$ because its structure is close to that of muscovite (more water, less $\mathrm{K}+$ ). Vermiculite is close to illite and chlorite, but shows swelling properties $(2.63 \%)$. Kaolinite has low values $(4.61 \%)$. Smectite and montmorillonite have rates of $10.53 \%$ and are generally calcic and rarely sodic. Chlorite is $7.24 \%$. The main fibrous clay mineral is attapulgite, which is joined by other iron oxides and hydroxides, such as hematite and goethite. Quartz, and calcite represent the majority of the components.

\subsection{Molluscan records}

This study presents the malacological richness of the Quaternary deposits of the Tebessa region, however, their systematics are a major problem, especially in the identification of broken shells. The identification of the recovered mollsucan fauna was based on Limondin-Lozouet (2002a), Limondin-Lozouet et al. (2012), Roubet and Hachi (2008) and Zerai (2006). Certain taxa, however are not found in these latest works, such as Coneuplecta confusa (Möllendorff, 1887). The identification of broken shells is sometimes impossible and therefore these fragments were not considered. On the other hand, several ecological groups were distinguished based on the reference collections at the National Inventory of Natural Heritage held at the National Museum of Natural History of Paris (MNHN) ${ }^{1}$. The universal German site "AnimalBase" of mollusks" ; and the Philippine conchology site of marine and continental malacological species ${ }^{3}$.

The 12 species identified for the Holocene are presented in (Tabs. 3 and 4, Figs. 3 and 4,). All the taxa that belong to the Morsott site are terrestrial pulmonary continental snails of small to medium size and decrease in abundance in the following order: Sphincterochilidae, Subulinidae, Hygromiidae, Helicidae, Zonitidae and Euconulidae (Tabs. 3 and 4, Figs. 3 and 4). In the different databases, many samples of Rumina decollata (Linnæus, 1758) of the family Subulinidae had high morphological variability. The ubiquitous taxa are Sphincterochila candidissima (Draparnaud, 1801) of the family Sphincterochilidae; and the taxon Cernuella globuloidea (Terver, 1839) of the family Hygromiidae. Other taxa are present in some levels and absent in others. Shell fragments were present in all the samples analysed, but did not allow for

\footnotetext{
$\overline{1<\text { http://www.mnhn.fr/en }>\text {. }}$

$2<$ http://www.animalbase.uni-goettingen.de/zooweb/servlet/Animal Base/search $>$.

${ }^{3}<$ https://www.conchology.be $>$.
} 


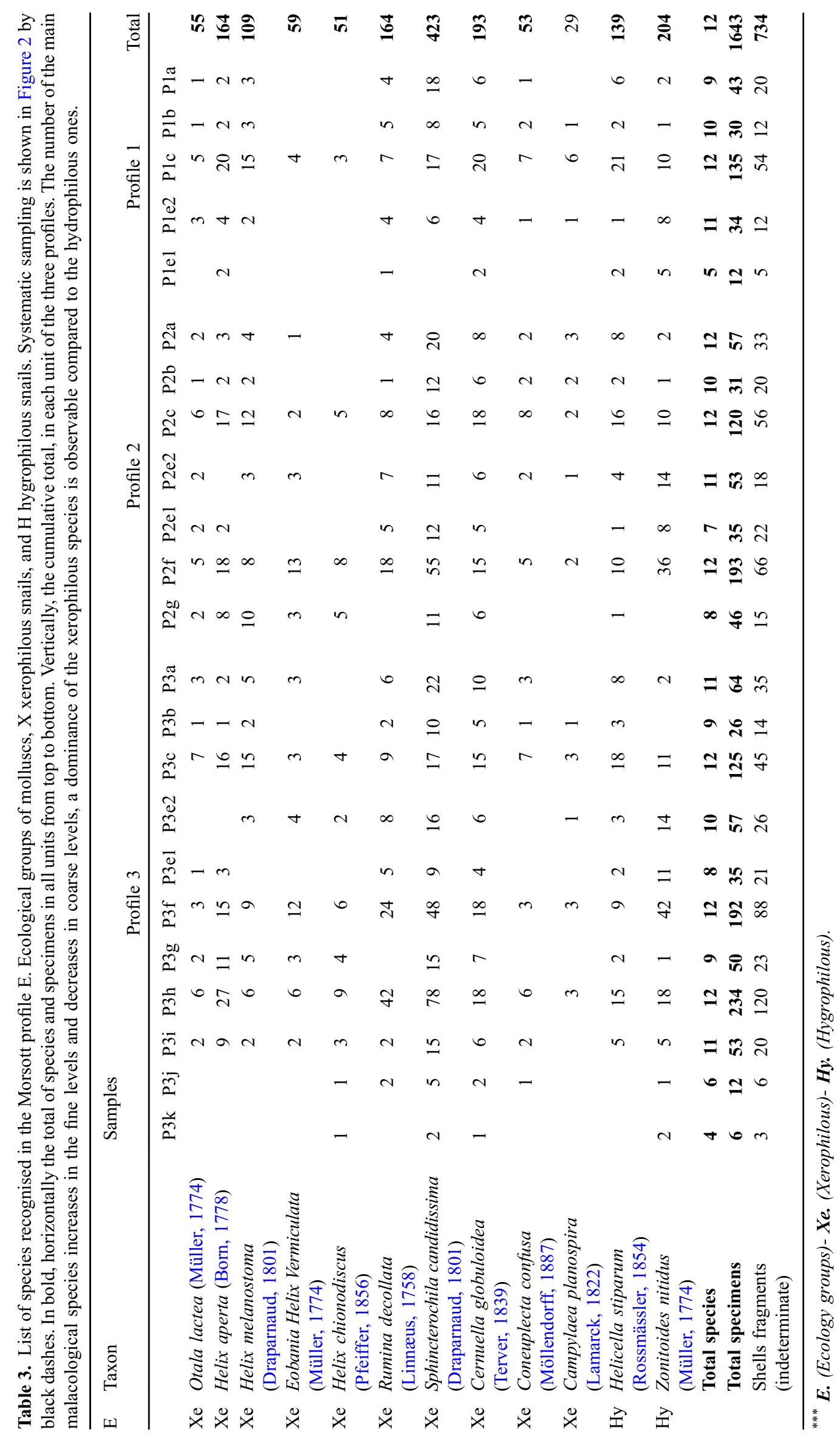


Table 4. Geographic distribution, mode of life and principal ecology groups of the Morsott species. This geographical distribution, ecology, lifestyle of the main species encountered, shows a Mediterranean fauna, in general all species harvested are terrestrial where humidity is variable from medium to low.

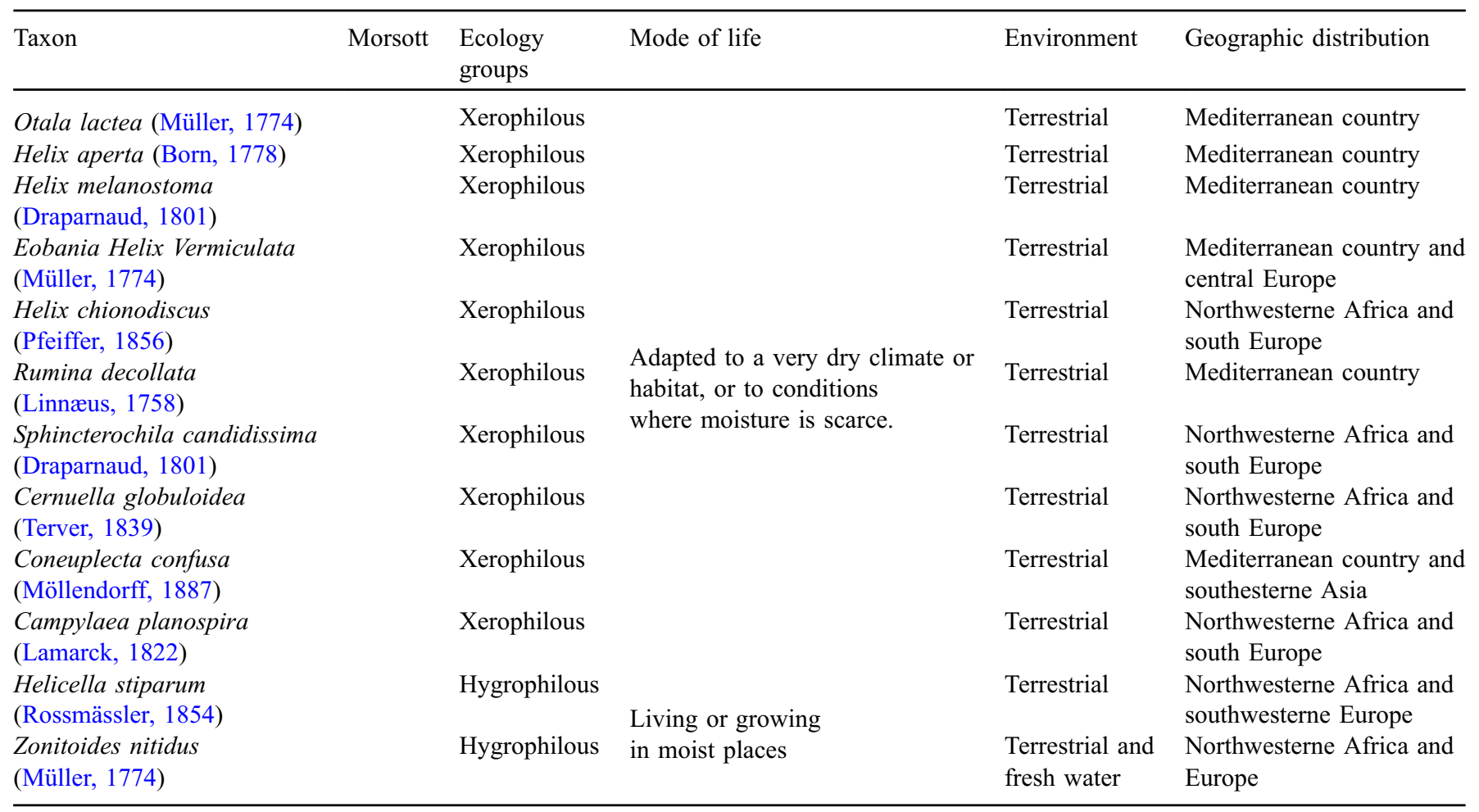

taxonomic discrimination. Recent studies have shown Rumina decollata may be sympatric without showing any hybridization (Mienis, 2008). The species Otala Lactea (Müller, 1774) was found in small quantities and was present in a wide variety of habitats, including arid lands, woodland and steppes, and is very common in the North of Africa (Ruiz et al., 2009).

Sphincterochila candidissima (Draparnaud, 1801) can be recognized by its very solid and thick chalky white shell, cupuliform globose, lack of belly button, and rounded or subangular periphery. The opening is rounded and very oblique (Ruiz et al., 2009), similar to Sphincterochila (Cariosula) baetica (Rossmässler, 1854). The shells have a 15 to 26.5 diameter and are between 13 to $21 \mathrm{~mm}$ in height. It lives in coastal areas and penetrates rivers, steppes, and arid lands exposed to the sun, as well as thin carbonaceous soils. It spends a large part of the year inactive (using an epiphragm to prevent desiccation) above the ground or partially buried. It is encountered in the western Mediterranean, so in north of Libya and Malta (Ruiz et al., 2009).

The species Cernuella globuloidea (Terver, 1839), has several synonyms: Helix globuloidea (Terver, 1839), Helicella globuloidea (Terver, 1839) and Xerophila globuloidea (Terver, 1839). This species is known by its large shells, which can be between 9 and $16 \mathrm{~mm}$ (height) and between 12 to $20 \mathrm{~mm}$ (diameter). It has a solid, helical, subglobosa, with 5.5 to 6 turns in a convex loop and final large and swollen turn; the shell is moderately marked by sutures; rounded openings. In general, they are uniformly white, however some species may have from one to three brown bands that could be discoloured or interrupted. The apex of the shell is usually brown or blackish in color. It lives in dry and sunny places, usually near the sea. It is present exclusively in North Africa (Tab. 4).

Helicella stiparum (Rossmässler, 1854), according to de Arrébola, (2001), it is known for its medium-sized, opaque shell. The most frequent colour is almost completely white, sometimes with a few dark bands (brown or grey-blue), especially in the dorsal position. It is a species capable of resisting extreme climatic conditions, and is characteristic of steppe environments, with a strong insolation. It lives on, or is sheltered by, rocks. The other species were directly described according to their resemblance to specimens encountered in Morocco and the Mediterranean region.

\subsection{Molluscan distribution}

According to the sampling carried out in the Morsott region, the terrestrial Holocene aforementioned malacological faunas (Tabs. 3 and 4, Fig. 5) indicate two ecological groups, which are either xerophilous and hygrophilous. Three malacological phases were defined in the studied profiles. At the bottom of units K to H, xerophilous Sphincterochila candidissima (Draparnaud, 1801) dominated, Cernuella globuloidea (Terver, 1839) in relation to hygrophilous Zonitoides nitidus (Müller, 1774) (Tab. 3, Fig. 5). There is a significant increase in the number of species in level $\mathrm{H}$, followed by a regression in unit $\mathrm{G}$, which is followed by a second malacological phase in unit $F$ which is presented by xerophilous and hygrophilous species, but the number is less important when compared to the first basal phase. The last phase is again dominated by xerophilous species, compared to 


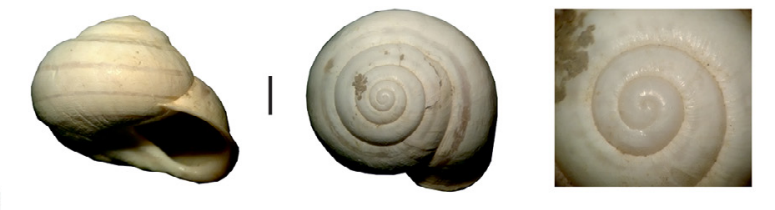

1
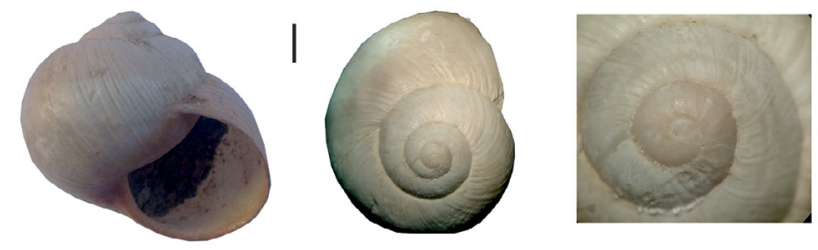

2
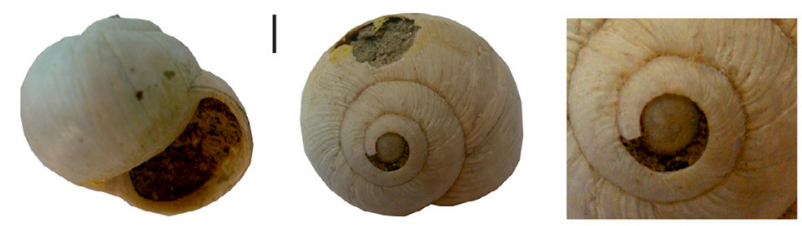

3
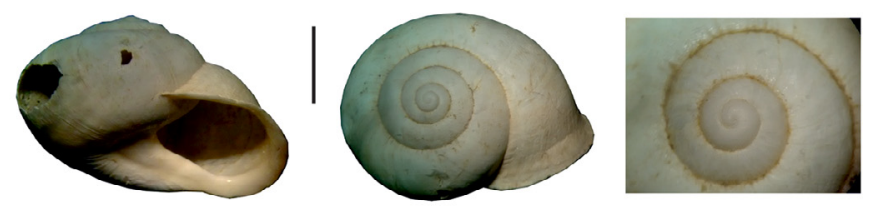

4

Fig. 3. Holocene species described in the Morsott region; $0.5 \mathrm{~mm}$ and $1 \mathrm{~cm}$ scale bar; apex magnification $3 \mathrm{X}$; (1) Otala lactea (Müller, 1774); (2) Helix aperta (Born, 1778); (3) Helix melanostoma (Draparnaud, 1801); (4) Eobania Helix Vermiculata (Müller, 1774). The snails analyzed are intact, the morphological features of the xerophililous species found at Morsott are clear, turns, aperture, apex, columella siphon, these different photos show apex and oral views.

the hygrophilous species. A clear increase in taxa is reported in level $C$ in profiles 3 and 2, which reduces towards the top of the unit. These peaks correspond to the sandy clayey silts deposits that are very rich in clay concretions (Fig. 5). Two phases are dated to within the Holocene, with an absolute age younger than $9700 \mathrm{cal}$. BP. One phase in the upper Pleistocene was dated to $13200 \mathrm{cal}$. BP. However, the bottom level (calcareously crusted and very poor in broken shells), is dated to the late Pleistocene dated $34300 \mathrm{cal}$. BP.

The variation in the abundance of molluscan taxa and their decrease in taxonomic diversity coincide with the alternations of sandy clayey silts, sandy silts and silty sands, which allow to tree biozones to be distinguished, where the oldest is found at the bottom, and the most recent at the top.

The first biozone, B1, is represented by levels $\mathrm{J}$ and $\mathrm{K}$, and at the base it is poor in shells up to the level H. It is represented by an essential peak (greater number), in all levels of the studied profiles. This biozone contains all the species described in large quantities. It begins with the deposit of silty sands that becomes more clayey in level $\mathrm{H}$, which allows for the evolution of snails and an increase in the number hygrophilous species. The first biozone ends in level G, where there is a significant reduction in the number of species (Figs. 2 and 5).

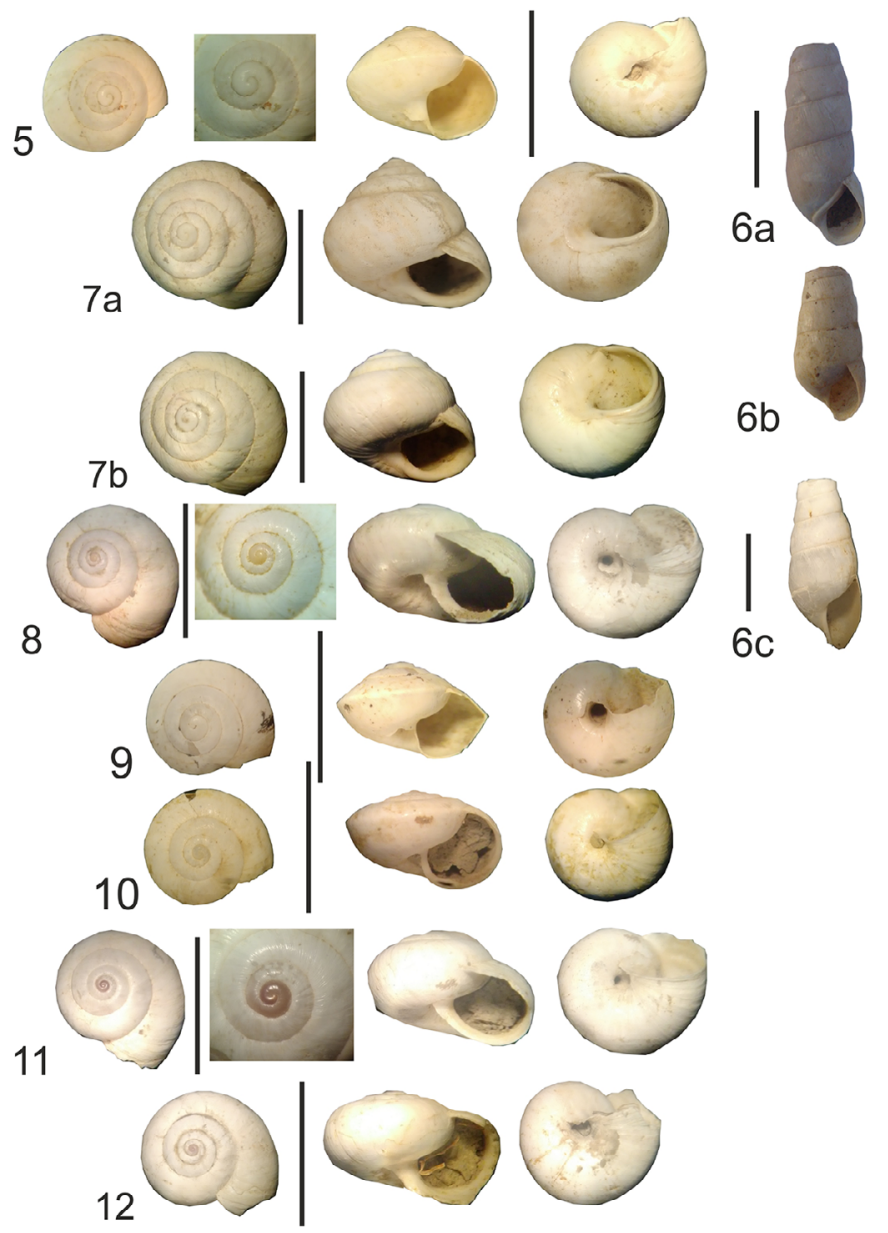

Fig. 4. Holocene species described in the Morsott region; (5) Helix chionodiscus (Pfeiffer, 1856); (6a-c) Rumina decollata (Linnæus, 1758); (7a, b) Sphincterochila candidissima (Draparnaud, 1801); (8) Cernuella globuloidea (Terver, 1839); (9) Coneuplecta confusa (Möllendorff, 1887); (10) Campylaea planospira (Lamarck, 1822); (11) Helicella stiparum (Rossmässler, 1854); (12) Zonitoides nitidus (Müller, 1774). $1 \mathrm{~cm}$ scale bar. Apex magnification 3 X. Global, apex, umbilical, and oral views of xerophilous and hygrophilous species.

The second biozone, B2, begins after the silty sands deposit episode of level $\mathrm{G}$ become more clayey in level $\mathrm{F}$, producing a wealth of malacological species. The number of xerophilous species decreases compared to the first biozone and is on the order of 145 species, whereas the number of hygrophilous is on the order of 48 species. (Tab. 3). This biozone ends in level E, which is rich in burrows and less rich in malacological species.

The third biozone, B3, includes level $\mathrm{C}$ and shows an increase in the number of xerophilous and hygrophilous species relative to levels $\mathrm{D}$ and $\mathrm{B}$, which delineate level $\mathrm{C}$ and fit to the upper dark level.

\section{Discussion}

The lithological description of the studied sequences shows two distinct levels $\mathrm{K}$ and L (Fig. 2, profile 3); at the bottom, there are calcareous concentrations where the rate of carbonates increases as a function of the depth. According to 


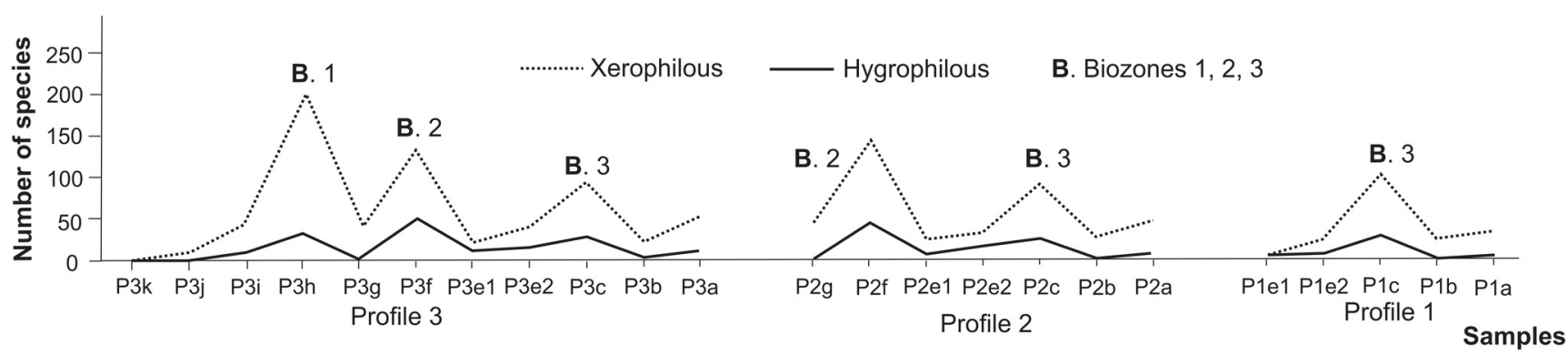

Fig. 5. Variation in the number of molluscan species in the Morsott profile. The variation of the molluscs as a function of the depth, shows an increase of the xerophilous and hygrophilous species in the fine levels (H, F, C), and a decrease in the other levels, which defines a biozonation in the studied profiles.

Taupin (1999), these are carbonates derived from neogenesis. This is explained by the rise carbonates-saturated water table. The low surface area of these concentrations is due to leaching of the soil by rainwater (Lamouroux, 1971). In the two lower levels, $\mathrm{K}$ and $\mathrm{L}$, the grains are almost completely carbonated (grain formation, nodules, and pinkish-colored calcareous crusts). The crust is also due to rapid drying (high evaporation) after an abnormally wet rainy season. The paleoenvironmental observations of the studied zone revealed two different parts, a basal post-glacial phase comprised of units $\mathrm{K}$ and $\mathrm{L}$, dated to $34346 \mathrm{cal}$. BP, according to other similar levels in Tunisia (Hentati, 1978), and an upper sequence of alternating subhumid (fine and dark units) and semi-arid phases (coarse and clear units). The post-glacial period corresponds to increased aridity in the region that was more marked than today (Jouve, 1988).

The top of the Holocene sequence alternates between fine and coarse levels, which contain argillaceous aggregates. The fine levels, rich in malacological species, show an increase in organic matter, iron oxide (hematite) and hydroxide (goethite), indicating a favourable environment for the development of vegetation and molluscan fauna. The clay minerals are inherited from the protolith and are certainly neoformed or transformed. The kaolinite is formed in well-drained soils by acidic waters, especially in arid periods, smectite is formed in poorly drained alkaline soils, and chlorite is formed during the diagenesis of sedimentary rocks. It is found in detrital elements in soils with a low aggressive climate. Attapulgite is found in confined environments (Chamley, 1989).

Visible clay aggregates in levels $\mathrm{C}, \mathrm{F}$ and $\mathrm{H}$ levels formed due to the agglutination of fines materials around minerals and have probably undergone pedogenesis (Miskovsky and Debard, 2002), giving rise to phases of accumulation. Three main cycles succeeded the formation of calcareous crusts and the deposition of silts in 2 or 3 successive episodes (Rognon et al., 1983; Rognon, 1984).

According to Erhart (1956), an isostasis cycle is represented in levels $\mathrm{K}$ and $\mathrm{L}$; it was a period of extreme stability during which the facies with zonal crusts were formed. A rhexistasis cycle, in which there is successive sedimentary deposition and remobilisations, is represented by levels A, B, D, E, G and I.

The biostasis cycle (podsolization) to which the early diagenetic facies refers is the result of a phase of significant intervention of the biosphere in the environment and is represented by the darker levels J, H, F and C (Fig. 6).
The studied Quaternary deposits probably underwent alluvial transport (fluvio-lacustrine or torrential) before their final placement. These deposits sometimes take the form of an alluvial cone, whose granularity gradually refines from upstream to downstream (decreasing in grade). This potentially alluvial deposit possibly included the deposition of silt during exceptional riverbed flooding events. Fluvial changes in the Mediterranean arid and semi-arid hydrographic systems more closely reflect the water and thermal components of the climate (Rohdenburg, 1989; Giessner, 1990), but the paleoenvironmental interpretation of alluvial changes remains difficult. The increased flooding has been interpreted as a result of changes in aridity, to either more arid (e.g., the Medjerda River in northern Tunisia (Faust et al., 2004) or less arid (e.g., the Tagus River in Spain (Benito et al., 2003) conditions, due to different flooding mechanisms. The deposition of alternating fine and coarse levels reveals the alternation of sub-humid and semi-arid phases or periods of desiccation (Carrion, 2002; Faust et al., 2004; Fletcher et al., 2007; Reed et al., 2001). The establishment of flood-related deposits remains uncertain. According to Faust et al. (2004), Fenech (2007), Giessner, (1990), Sancho et al. (2008) and White et al. (1996), arid to semi-arid watersheds show decreased flooding with the formation of soils under more humid conditions. The thenviable dense vegetation reduces the surface runoff, whereas drier conditions undermine vegetation, which leads to alluvial activity and increased flooding (Rohdenburg, 1989).

The alluvium provides the ideal support for the development of plants and malacological species (Fig. 7).

Changes in the basal level of rivers in postglacial periods are related to changes in mean sea level; coastal areas are the most affected by these changes, but northern hemisphere interior areas underwent a rise in humidity, allowing pedogenesis and the development of pulmonate gastropod species.

The molluscan concentrations corresponding to the biozones B1, B2 and B3, are concordant with the fine clayloam levels $\mathrm{C}, \mathrm{F}$ and $\mathrm{H}$. This abundance increases in profiles 1 , 2 and 3 from top to bottom, showing favourable conditions for molluscs (presence of moisture and vegetation cover). Biozones of the same lithological level contain similar concentrations. The B3 biozone is significant because it represents the transition between the Pleistocene and the Holocene during which the climate changes from arid to subarid and sub-humid. A depleted abundance of molluscs indicates that the climatic conditions were detrimental to molluscan development. 

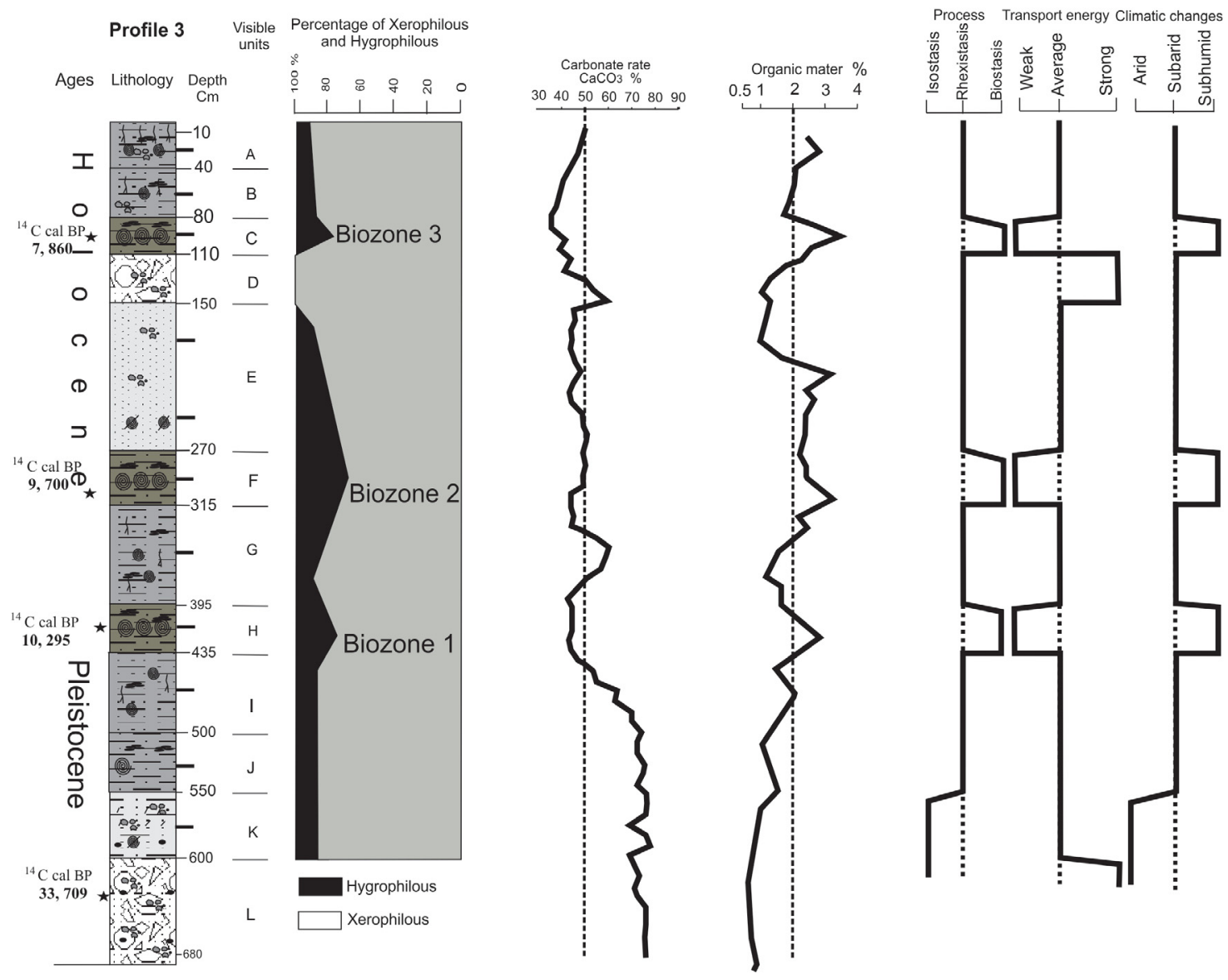

Fig. 6. Paleoenvironmental synthesis of the Morsott profiles. Three biozones are distinguished, due to climatic variations, marked by the peaks of variations of the geochemical parameters, energy of the agent of the transport and dynamic process of the emplacement of the deposits.

The malacological succession of Morsott shows environmental episodes of terrestrial phases in the Holocene (biozones B1, B2 and B3) (Fig. 6). Preboreal wetland taxa (Zonitoides nitidus) are identified (Limondin-Lozouet and Preece, 2004; Meyrick, 2000; Preece and Bridgland, 1999). In Europe, these assemblages represent pioneer fauna that colonized habitats provided after an unfavourable climatic phase, which in this case was the appearance of post-glacial warming after the glacial retreat.

The number of shells is generally low in the early sets of I and $J$, probably due to climatic conditions which were detrimental to snails, but malacological communities developed rapidly and diversified (Fig. 6). The biozones of concern contain assemblages dominated by hygrophilous molluses, which can withstand temporary desiccation phases. They imply the temporary appearance of a lake system due to the flooding of wadis or stagnation of meteoric water during rainy periods, but the irregularities in the number of shells indicate temporary drying episodes. Terrestrial species were dominant throughout the Holocene. Aquatic species are absent in this region, which suggests that the waterway did not last long swamps. The paleoenvironmental study has shown that water drainage is linked to climatic aridification, which allowed the deposit of coarse sedimentary units.

\section{Conclusions}

The molluscan study carried out on the Morsott deposits shows a succession of sandy clayey silts levels interspersed with sandy silts that record variations in sediment transportation regime. The region has undergone several phases of accumulation due to alluvial or torrential sediment supplies, while the development of swamps is indicated by the presence of attapulgite clay minerals, characteristic of confined environments.

Three sequences encountered in the Morsott site mark the alternation of rich molluscan levels with low levels of abundance; the rich levels coincide with the fine silty clay levels, with a rise in the concentration of organic matter. The absolute dating of these levels gave a Holocene age.

The Morsott Holocene sequence shows that the application of an appropriate methodology can reveal significant molluscan successions that document paleoenvironmental changes. The three Holocene biozones coincide with fine sediment levels and indicate the alternation of climatic phases varying from sub-arid to sub-humid. These sub-humid phases allowed the development of molluscan populations. Other species show the variation of the basal level of wadis and even hydraulic variations in watersheds. The molluscan fauna 


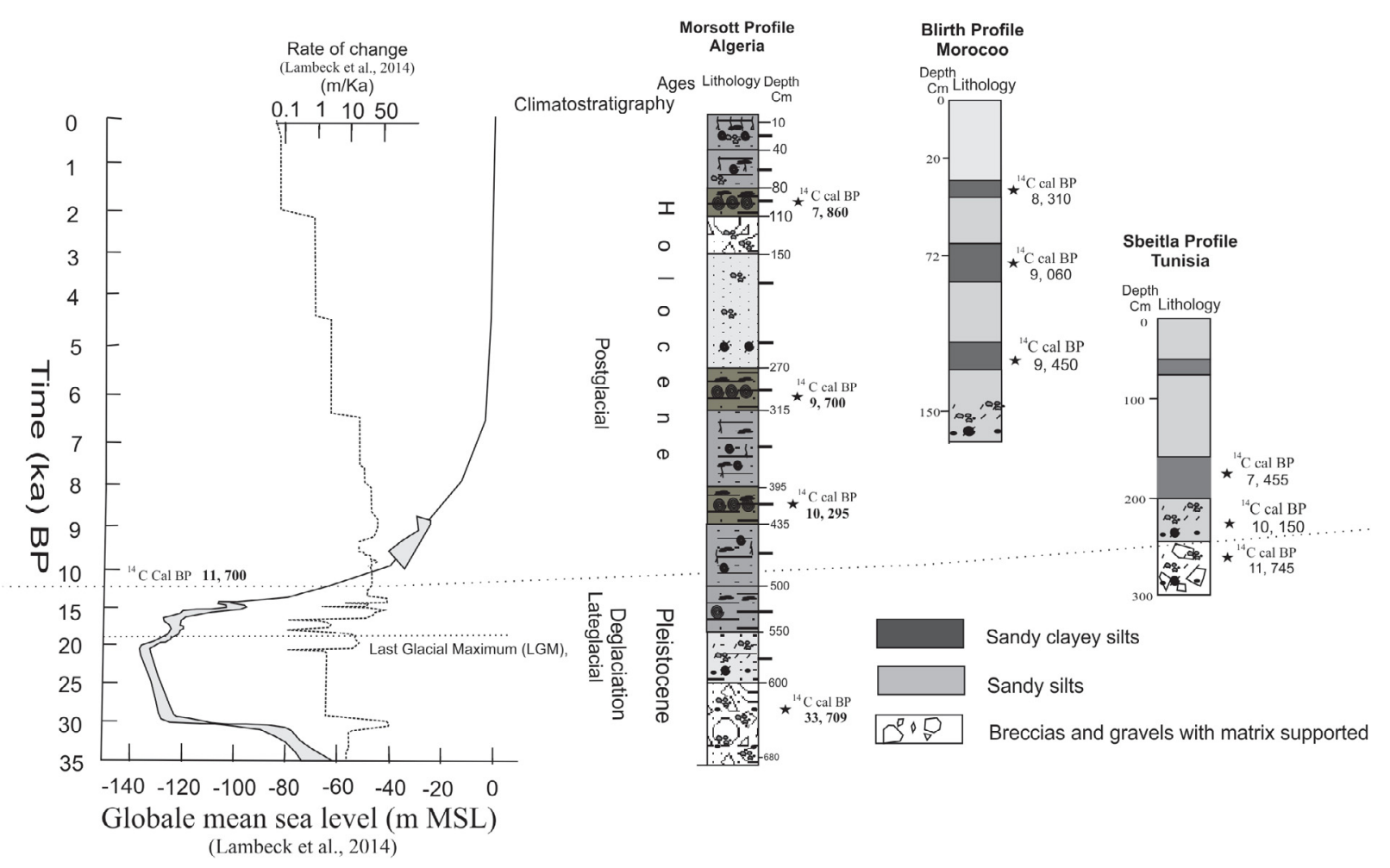

Fig. 7. Geochronological approach of the Quaternary deposits of the Morsott profiles, along with the profiles of Blirth in Morocco and Sbeitla in Tunisia. The correlation made between already established profiles, in Tunisia and Morocco, indicates that quaternary deposits are variable in time, alternating wet and sub-arid phases, some parts are absent because of the alteration, the basic level is met in Algeria and Tunisia, in Morocco the profiles made of Holocene sediments did not reach the Pleistocene base. The absolute ages range from the upper Pleistocene at the base to the Holocene at the top. Mean sea level variation curves show the transition from a late glacial period to a post-glacial period. The sea level elevation induces the raising of the basal levels of the various wadis (Lambeck et al., 2014).

offer interesting perspectives on paleobiodiversity and also on the development of modern fauna. The reduction in the number of species at the top of the sequence and the current disappearance of certain species can be explained by anthropogenic effects; human consumption of certain species, such as Otala lactea, Helix aperta, Helix melanostoma and Eobania Helix Vermiculata reduced and eradicated their populations; while the cultivation of superficial lands demolished the ecological niches of these species. In Algeria, hydric variations in watersheds during the Holocene have not been precisely documented, prompting the development of a molluscan fauna survey that will allow for paleoenvironmental correlations, which include profiles of Sbeitla in Tunisia, and Blirth in Morocco which show a similar climatic event chronological at the end of the Quaternary.

\section{References}

Benito G, Sopena A, Sanchez-Moya Y, Machado MJ, Peret-Gonzalez A. 2003. Palaeoflood record of the Tagus River (Central Spain) during the Late Pleistocene and Holocene. Quaternary Science Reviews 22: 1737-1756.

Born I. 1778. Index rerum naturalium Musei Cæsarei Vindobonensis. Pars I. ma. Testacea. Verzeichniß der natürlichen Seltenheiten des k. k. Naturalien Cabinets zu Wien. Erster Theil. Schalthiere. pp. [140], 1-458, [1-82]. Vindobonæ. (Kraus).
Bourguignat JR. 1864. Malacologie de l'Algérie, ou, Histoire naturelle des animaux mollusques terrestres et fluviatiles recueillis jusqu'à ce jour dans nos possessions du Nord de l'Afrique. Tome I et II. Paris : Challamel aine.

Bronk Ramsey C. 2009. Bayesian analysis of radiocarbon dates. Radiocarbon 51: 337-360.

Carrion JS. 2002. Patterns and processes of Late Quaternary environmental change in a montane region of southwestern Europe. Quaternary Science Reviews 21: 2047-2066.

Chamley H. 1989. Clay sedimentology. Berlin Heidelberg: SpringerVerlag, 623 p. ISBN 978-3-642-85918-2.

Chellat S. 2009. Paleo-environnement des terrasses fluviatiles et alluvionnaires de l'oued mellegue et ses affluents approche sedimentologique, stratigraphique et magnétique Tébessa. Algérie : Université de Tébessa, $165 \mathrm{p}$.

Cote M. 1998. Les régions bioclimatiques de l'Est algérien. Rhumel 6: 57-71.

Crann CA, Murseli S, St-Jean G, Zhao X, Clark ID, Kieser WE. 2017. First status report on radiocarbon sample preparation at the A.E. Lalonde AMS Laboratory (Ottawa, Canada). Radiocarbon 59(3): 695-704. DOI: 10.1017/RDC.2016.55.

Defaflia N. 2013. Étude sédimentologique et paleoenvironnementale des formations quaternaires alluvionnaires de l'oued birzguel, el ma el abiod, wilaya de Tébessa. Algérie. Courrier du Savoir 17, décembre 2013: 139-147.

De Arrébola JR. 2001. Nuevos datos sobre dos especies del género Helicella Ferussac, 1821 en Andalucía: Helicella stiparum 
(Rossmässler, 1854) y Helicella gasulli Ortiz de Zárate, 1950 (Gastropoda: Pulmonata). Malakos: Boletín informativo 6: 2-11.

Djerrab A, Spassov S, Defaflia N, Hus J, Abdessadok S, RuaultDjerrab M, et al. 2013. The middle palaeolithic site of Birzgane (Tebessa, Algeria): Rock magnetic property characterisation and past rainfall reconstruction. Science Direct Elsevier. Journal of Quaternary International 320(2014): 63-74.

Draparnaud JPR. 1801. Tableau des mollusques terrestres et fluviatiles de la France. Montpellier, Paris : Renaud; Bossange, Masson \& Besson, pp. [1-2], 1-116.

Dubourdieu G. 1956. Étude géologique de la région de l'Ouenza (confins algéro-tunisiens). Thèse des Sciences, Paris, Publications du Service de la Carte Géologique de l'Algérie, N10,1: 659.

Erhart H. 1956. La genèse des sols en tant que phénomène géologique. MASSON et CIE, Paris, Collection Évolution des Sciences, $90 \mathrm{p}$.

Evans JG. 1972. Land snails in archaeology. London: Seminar Press.

Faust D, Zielhofer C, Baena R, Diaz del Olmo F. 2004. Highresolution fluvial record of late Holocene geomorphic change in northern Tunisia: climatic or human impact? Quaternary Science Reviews 23: 1757-1775.

Fenech K. 2007. Human-induced changes in the environment and landscape of the maltese islands from the neolithic to the 15 th Century AD. Oxford: Archaeopress.

Fletcher WJ, Boski T, Moura D. 2007. Palynological evidence for environmental and climatic change in the lower Guadiana valley, Portugal, during the last 13000 years. The Holocene 17: 481-494.

Folk R. 1954. The distinction between grain size and mineral composition in sedimentary-rock nomenclature. The Journal of Geology 62(4): 344-359

Giessner K. 1990. Geo-ecological controls of fluvial morphodynamics in the Mediterranean subtropics. GeoöKodynamik 11: 17-42.

Gouaidia L. 2008. Influence de la lithologie et des conditions climatiques sur la variation des parametres physico-chimiques des eaux d'une nappe en zone semi aride, cas de la nappe de meskiana nord-est algerien. Thèse de doctorate en science, Université de Annaba, $150 \mathrm{p}$.

Haddoumi H, Aouraghe H, Limondin-Lozouet-Lozouet N, El Harradji A, Sala R, El Hammouti K. 2008. La malacofaune continentale holocène du bassin de l'oued El Haï (Hauts plateaux septentrionaux, Maroc oriental) : premières données paléontologiques et paléoenvironnementales. Actes de la RQM4, Oujda, Morocco, pp. 280-290.

Hentati MA. 1977. Conditions d'équilibre et de déséquilibre des divers types de milieu dans le djebel Semmama et sur son piedmont. Thèse $3^{\mathrm{e}}$ cycle, Université de Strasbourg, $266 \mathrm{p}$.

Hentati MA. 1978. Caractéristiques du périglaciaire hérité dans la partie occidentale de la dorsale Tunisienne. Collection sur le Périglaciaire d'altitude du domaine méditerranéen et abords. Strasbourg, (France): Association Géogrographie D’Alsace, pp. 123-133.

Jouve A. 1988. «Tardiglaciaire». In: Dictionnaire de la Préhistoire: Leroi-Gourhan André Directeur, ed. France : Presses Universitaires de France, 1159 pp.

Lamarck JPBA de Monet de. 1822. Histoire naturelle des animaux sans vertèbres, présentant les caractères généraux et particuliers de ces animaux, leur distribution, leurs classes, leurs familles, leurs genres, et la citation des principales espèces qui s'y rapportent; précédée d'une introduction offrant la détermination des caractères essentiels de l'animal, sa distinction du végétal et des autres corps naturels, enfin, l'exposition des principes fondamentaux de la zoologie. Tome sixième. $2^{\mathrm{e}}$. partie. Paris, pp. [1-3], 1-232.
Lambeck K, Rouby H, Purcell A, Sun Y, Sambridge M. 2014. Sea level and global ice volumes from the last glacial maximum to the holocene. Proceedings of the. National Academy of Science of the United States of America 111: 15296e15303

Lamouroux M. 1971. Étude de sols formes sur roches carbonatees (pédogénèse fersiallitique au Liban cah. O.R.S.T.O.M., sér. pédol., vol. ix, n 3 -1971) résumé d'une thèse présentée en mars 1971 à la faculté des sciences de l'université de Strasbourg pour obtenir le grade de docteur en sciences naturelles (1971) 6 .

Lefèvre D. 1985. Les formations plio-pléistocènes du Bassin de Ksabi (Moyenne Moulouya, Maroc). Ph.D. Thesis, France,Université de Bordeaux I.

Lefèvre D. 1989. Formations continentales pléistocènes et paléoenvironnements sédimentaires dans le bassin de Ksabi (Moyenne Moulouya, Maroc). Bulletin de l'Association française pour l'Étude du Quaternaire 2: 101-113.

Lefèvre D, Ballouche A. 1991. Évolution des paléoenvironnements de la marge Nord-saharienne à l'Holocène : exemple du bassin de Ksabi (Moyenne Mou-louya, Maroc). Cahiers du Quaternaire 16: 451-477.

Limondin-Lozouet N. 2002a. Analyse malacologique du site de Choisey/Aux Champins. In: Séara F, Rotillon S, Cupillard C, (dir.) : Campements mésolithiques en Bresse jurassienne, Choisey et Ruffey-sur-Seille (Jura), documents d'Archéologie Française, 92: 101-104

Limondin-Lozouet N. 2002b. Les mollusques continentaux. In: Miskovsky JC, ed. Géologie de la Préhistoire: méthodes, techniques, applications. Géopré: Presses Universitaires de Perpignan, pp. 773-784.

Limondin-Lozouet N, Preece RC. 2004. Molluscan successions from the Holocene tufa of St-Germain-le-Vasson, Normandy (France) and their biogeographical significance. Journal of Quaternary Science 19: 55-71.

Limondin-Lozouet N, Haddoumi H, Lefèvre D, Ghamizi M, Aouraghe H, Salel T. 2012. Holocene molluscan succession from NE Morocco Palaeoenvironmental reconstruction and biogeographical implications. Science Direct elsevier. Journal of Quaternary International 302(2013): 61-76

Linnæus C. 1758. Systema naturæ per regna tria naturæ, secundum classes, ordines, genera, species, cum characteribus, differentiis, synonymis, locis. Tomus I. Editio decima, reformata pp. [1-4], 1824. Holmiæ. (Salvius).

Lozek V. 1964. Quartärmollusken der Tschechoslowakei. Rozpravy Ústredního Ústavu Geologického 31, Praha.

Mebarki A. 2005. Hydrologie des bassins de l'Est Algérien: ressources en eau, aménagement et environnement. Thèse de doctorat d'état, Université de Constantine, $360 \mathrm{p}$.

Meyrick RA. 2000. Holocene molluscan faunal history and environmental change from a tufa at Direndall, Luxembourg. Bulletin de la Société Préhistorique Luxembourgeoise 22: 55-75.

Miskovsky JC, Debard E. 2002. Préhistoire et paléoenvironnements quaternaires dans le bassin méditerranéen. Paris : Laboratoire de préhistoire de l'Université de Perpignan, pp. 495-498

Mienis HK. 2008. Does Rumina saharica Pallary, 1901 occur in France? Malaco 5: 229-230.

Möllendorff WV. 1887. The landshells of Perak. The Journal of the Asiatic Society of Bengal 55: 299-316.

Müller OF. 1774. Vermivm terrestrium et fluviatilium, seu animalium infusoriorum, helminthicorum, et testaceorum, non marinorum, succincta historia. Volumen alterum. - pp. I-XXXVI [= 1-36], 1214, [1-10]. Havniæ \& Lipsiæ. (Heineck \& Faber). 
Pallary P. 1901. Sur les mollusques fossiles, terrestres et saumatres de 1Algérie. Mémoire Sociéte Géologie de France. (Paleontologie): $1-123$.

Pfeiffer L. 1856. Bericht über weitere Mittheilungen des Herrn Zelebor. Malakozoologische Blätter 3: 175-186, Taf. 2. Cassel.

Puisségur JJ. 1976. Mollusques continentaux quaternaires de Bourgogne. Mémoires Géologiques de l'Université de Dijon 3, Doin, Paris.

Preece RC, Bridgland DR. 1999. Holywell Coombe, Folkestone: a 13000 -year history of an English Chalkland valley. Quaternary Science Reviews 18: 1075-1125.

Reed JM, Stevenson, AC, Juggins S. 2001. A multi-proxy record of Holocene climatic change in southwestern Spain: the Laguna de Medina, Ca' diz. The Holocene 11: 707-719.

Reimer PJ, Bard E, Bayliss A, Beck JW, Blackwell PG, Bronk Ramsey $\mathrm{C}$, et al. 2013. IntCal13 and MARINE13 radiocarbon age calibration curves 0-50000 years calBP. Radiocarbon 55(4): 1869-1887.

Rognon P. 1984. Signification dynamique et climatique des formations et terrasses fluviatiles en Afrique du Nord et au Proche-Orient. Rapport, Bulletin de l'Association française pour l'étude du quaternaire 21(1): 61-169.

Rognon P, Levy A, Ballais J.-L, Goude G, Riser J. 1983. Essai d'interprétation des coupes du Quaternaire récent de l'oued El Akarit (Sud tunisien). Géologie méditerranéenne 10(2): 71-91.

Rohdenburg H. 1989. Landscape ecology, geomorphology. Reiskirchen, (Germany): Catena.

Roubet C, Hachi S. 2008. Leucochroa Candidissima Draparnaud, Revue Encyclopédie Berbère 35: 4366-4374. disponible sur : http:// encyclopedieberbere.revues.org/328\#entries.

Rossmässler EA. 1854-1859. Iconographie der Land- und Süsswassermollusken Europa's, mit vorzüglicher Berücksichtigung kritischer und noch nicht abgebildeter Arten. III. Band. pp. Heft 13/14: I-VIII [= 1-8], 1-39, Heft 15/16: I-VIII [= 1-8], 41-77, [1], Heft 17/ 18: I-VIII [= 1-8], 81-140, Taf. 61-90. Leipzig. (H. Costenoble).

Roubet C, Hachi S. 2008. Leucochroa Candidissima Draparnaud, Revue Encyclopédie Berbère 35: 4366-4374. Disponible sur: http://encyclopedieberbere.revues.org/328\#entries.
Rousseau DD. 1986. Intérêt paléobiogéographique de Pupilla loessica Lozek et de Vallonia tenuilabris (A. Braun) pour le Pléistocène Ouest-européen. In: Comptes Rendus de l'Académie des Sciences Paris 303: 257-262.

Rousseau DD. 1987. Paleoclimatology of the Acenheim Series (Middle and Upper Pleistocene, Alsace, France). A malacological analysis. Palaeogeography, Palaeoclimatology, Palaeoecology 59: 293-314.

Ruiz A, Carcaba A, Porras AI, Arrébola JR. 2009. Caracoles terrestres de Andalucía, Guía y manuel de identificación. Fundación Gypaetus. 2006. ISBN:84-935194-2-1. 303 p.

Sancho C, Pena JL, Munoz A, Benito G, McDonald E, Rhodes EJ, et al. 2008. Holocene alluvial morphopedosedimentary record and environmental changes in the Badenas Reales Natural Park (NE Spain). Catena 73: 225-238.

Sparks BW, Grove AT. 1961. Some Quaternary fossil non-marine Mollusca from the central Sahara. Journal of the Linnean Society of London 44: 355-364.

Taupin J-D. 1999. Interprétation sur l'origine des nodules carbonatés des terrasses du Niger aux environs de Niamey (Niger) au moyen des outils isotopiques et géochimiques (colloque international: apport de la géochimie isotopique dans le cycle de l'eau Tunisie (Hammamet): 6, 7, 8s. THE/ORSTOM, domaine Universitaire, Grenoble, France (1997) 4.

Terver AP. 1839. Catalogue des Mollusques terrestres et fluviatiles observés dans les possesions francaises au Nord de l'Afrique. Lyon: Baillière, Crochard \& Savy, 39 p.

White K, Drake N, Millington A, Stokes S. 1996. Constraining the timing of alluvial fan response to Late Quaternary climatic changes, southern Tunisia. Geomorphology 17: 295-304.

Zerai K. 2006. Thèse d'état en géographie physique les environnements holocènes et actuels dans le bassin versant de l'oued Sbeïtla (Tunisie centrale) (2006) Université de Paris VII Denis Diderot, $337 \mathrm{p}$.

Zeuner FE. 1970. Dating the past. An introduction to geochronology. Londres: Methuen \& Co., 4 éd. 516 p.

Cite this article as: Chellat S, Toubal L, Djerrab A, Bourefis A, Hamdi-Aissa B, Salmi-laouar S. 2018. Molluscan and sedimentological sequences of the late Quaternary deposits of Morsott region (NE Algeria) and their paleoenvironmental implication, BSGF - Earth Sciences Bulletin 189: 17. 